Volume 5, Issue 1, February 2020, pp. 69-79

DOI: $10.23917 /$ jramathedu.v5i1.9818

p-ISSN: 2503-3697, e-ISSN: 2541-2590

\title{
Exploring senior high school student's abilities in mathematical problem posing
}

\author{
Muhtarom Muhtarom*, Ali Shodiqin, Novita Astriani \\ Department of Mathematics Education, Universitas PGRI Semarang, Indonesia \\ *Corresponding author: muhtarom@upgris.ac.id
}

\begin{tabular}{l} 
ARTICLE INFO \\
\hline Article history: \\
Received: 8 January 2020 \\
Revised: 18 February 2020 \\
Accepted: 20 February 2020 \\
Published online: 28 February \\
2020 \\
Published regularly: February \\
2020
\end{tabular}

Keywords:

Pre-solution posing, withinsolution posing, post-solution posing

\begin{abstract}
The ability of problem posing is very essential for the student's. However, there are still many students who don't realize the importance of these abilities. This research describes the senior high school student's ability in mathematical problem posing, especially in the material system of linear equations in three variables. Research data were collected from 7 student's using written test and interview techniques. The validity of the data used triangulation methods by comparing the results of written tests and interviews. Data were coded, simplified, presented, and triangulated for the credibility and conclusion drawing. The results show that there were still very few students who have all three classifications of problem posing abilities, namely pre-solution posing, within-solution posing, and post-solution posing. Students who have the ability of pre-solution posing can ask questions based on the data provided and can arrange problem solving. Students who have the ability of within-solution posing can write what is given and asked of the problem, raise supporting questions which is relevant to the problem and arrange solutions to the supporting questions and problems that are given correctly. Students who have the ability of post-solution posing can raise similar mathematics problem after solving the problem. Students can also arrange solutions to problems that have been made. Teacher needs to practice pre-solution posing, within-solution posing, and post-solution posing to the students.
\end{abstract}

(C) 2020 Universitas Muhammadiyah Surakarta

\section{Introduction}

One of the obstacle in learning mathematics are students experiencing difficulties in solving math problems (Murtianto, Muhtarom, Nizaruddin, \& Suryaningsih, 2019; Siswono, 2011). Siswono (2011) explains that these obstacles can be overcome if students have problem posing abilities. Using the problem posing ability, students can discover knowledge through the efforts for relationships of information learned. Students can ask questions based on the conditions exist: mathematical problems have been solved and the information is given. Problem posing ability can encourage students to make connections between different concepts so that they can build their understanding (Mahmudi, 2011; Rachmawati, Sugandi, \& Prayitno, 2019). Study of Silver and Cai (1996) resulted that problem-posing has a positive impact on students' ability in problem solving. Problemposing can help students apply problem solving abilities (Arofah \& Masriyah, 2019;

To cite this article:

Muhtarom, M., Shodiqin, A., \& Astriani, N. (2020). Exploring senior high school student's abilities in mathematical problem posing. JRAMathEdu (Journal of Research and Advances in Mathematics Education), 5(1), 69-79. doi:https://doi.org/10.23917/jramathedu.v5i1.9818 
Ghasempour, Bakar, \& Jahanshahloo, 2013; Rosli, Capraro, \& Capraro, 2014). Besides, Rosli,

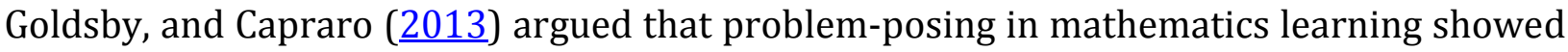
positive and meaningful results on mathematics achievement, problem solving abilities, and students' attitudes towards mathematics. Problem posing is a task that asks students to formulate problems and create problems.

Researches categorized in problem posing have been described by Silver and Cai (1996) and Stoyanova (2005). Silver and Cai (1996) classified problem-posing into presolution posing, within-solution posing, and post-solution posing. Pre-solution posing is students who express problems from the data provided using their sentences, and arrange problem solving under the problems raised. Within-solution posing is students who posing relevant questions or questions that can support problem solving from a given problem, arranging solutions to relevant questions and using relevant problem solving to arrange problem solving. Students who have the post-solution posing ability can raise new problems that similar to the solved problems, and arrange solutions to the problems that have been made. In making new questions based on statements given, students can do, among others, by giving questions about the specific purpose of the information added, the addition of information, and the general purpose of the problem. Arikan and Ünal (2015) states that formulation of a problem that has been resolved previously can be done by adding information, changing the context, combination, changing what is given, changing what is asked, simplifying the problem, exchanging what is given by what was asked.

Stoyanova (2005) explains three categories in problem posing, namely reformulation, reconstruction and imitation of the problem. Problem reformulation is when students rearrange problems with the information, it does not change nature of the problem. Adding information does not change the problem. Problem reconstruction is the activity of modifying the nature of the initial problem but not changing the intent or purpose of the problem. The imitation of the problem is when students arrange problems with the addition of structures related to information provided, change the intent and purpose of the problem. Problem posing can be interpreted as an activity asking students to ask mathematical problems based on the information provided, as well as solving problems that have been made. Thus, problem-posing is not limited to the formation of new problems, but a subject can mean reformulating the problem given. Table 1 categories

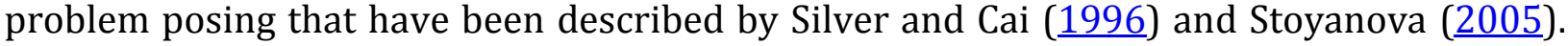
Furthermore, problem posing in this research was used the theory described by Silver and Cai (1996).

Table 1

Categories problem posing

\begin{tabular}{|c|c|c|}
\hline Silver and Cai (1996) & Stoyanova $(\underline{2005})$ & Description \\
\hline Pre-solution posing & Reformulation & $\begin{array}{l}\text { Recognizing or using directly the information in the } \\
\text { original problem. }\end{array}$ \\
\hline Within-solution posing & Reconstruction & $\begin{array}{l}\text { Arrange relevant questions that can support problem } \\
\text { solving and arrange the solutions to relevant } \\
\text { questions. }\end{array}$ \\
\hline Post-solution posing & Imitation & $\begin{array}{l}\text { Create new problems and arrange solutions to } \\
\text { problems that have been made. }\end{array}$ \\
\hline
\end{tabular}

Problem-posing ability can make students actively learn mathematics (Barlow \& Cates, 2006) and assist students in developing problem solving ideas (English, 1997; Xia, Lu \& Wang, 2008). Students who have good problem posing abilities, also have good problem solving abilities (Ayllón, Gomez, \& Ballesta-Claver, 2016; Silver \& Cai, 1996; Xie \& Masingila, 2017). It means that the ability of problem posing needs to be owned by 
students. However, this research has not yet described the students' problem posing abilities. From above analysis, it is urgent to conduct this research in order to make description of students' problem posing abilities so that they can be a foothold in developing students' problem solving abilities. Based on the description above, this research will focus on description of students' the problem-posing ability.

\section{Research Methods}

This research used a qualitative method because it is carried out in reality or natural conditions and is not manipulated by researchers. The characteristic of concern is the meaning to describe the facts. This research explored the ability of students posing problems, especially in the system of linear equation systems on three variables. The research was conducted on 40 students of Senior High School in Pati Regency, Central Java. The research participants were selected using a purposive sampling technique that has good communication skills both verbally and in writing based on the consideration of the mathematics teacher. The instruments used in this research was a written test (see the Appendix) and a guided interview based on the problem posing task. Before using the instrument, the instruments was first validated by three validators who are experts in mathematics education and were declared eligibility to be used to measure students' problem posing abilities.

The data were collected in two stages. The first stage of data collection is to provide written tests to 40 senior high school students. Table 2 presents a clear description of the results of the data analysis of the 40 students. The second stage is conducting interviews with research subjects, where the interview time is based on mutual agreement. Then seven subjects were chosen, namely A1, B3, C1, D3, E2, F3, and G5; who have good communication skills to do in-depth interviews to get a comprehensive picture of the problem-posing of students' abilities. Furthermore, the data was validated using the triangulation method. Results of the triangulation was valid participant data for describing of the problem-posing ability of students (Miles \& Huberman, 2002; Moleong, 2008). Qualitative data had been analyzed using data reduction technique, data presentation, and conclusion (Miles \& Huberman, 2002). These three data analysis activities were not hierarchical but were interwoven interrelated activities from before, during and after data collection.

Table 2

Research participants

\begin{tabular}{llc}
\hline \multicolumn{1}{c}{ Ability of Problem-Posing } & \multicolumn{1}{c}{ Participant Code } & $\begin{array}{c}\text { Selected Participant } \\
\text { With Code* }\end{array}$ \\
\hline Pre-solution posing & A1*, A2, A3, A4, A5 & A1 \\
Within-solution posing & B1, B2, B3* & B3 \\
Post-solution posing & C1*, C2, C3, C4, C5, C6, C7, C8 & C1 \\
Pre-Within solution posing & D1, D2, D3* & D3 \\
Pre-Post solution posing & E1, E2*, E3, E4, E5, E6, E7, E8, E9 & E2 \\
Within-Post solution posing & F1, F2, F3*, F4 & F3 \\
Pre-Within-Post solution posing & G1, G2, G3, G4, G5*, G6, G7, G8 & G5 \\
\hline
\end{tabular}

\section{Results and Discussion}

Figure 1 obviously shows that A1 had the ability of pre-solution posing. Participant can only raise questions based on the data provided and can arrange solutions to problems using mixed methods: elimination and substitution. Participant B3 had the ability of 
within-solution posing. The participant can write down what is given and what is asked of the problem given and raise questions relevant to the problem given to support problem solving, for example how much is the price of $1 \mathrm{~kg}$ of thorny palm, $1 \mathrm{~kg}$ of orange, and $1 \mathrm{~kg}$ of apple? Furthermore, the participant can arrange the completion of relevant questions that have been raised by using the determinant method. Participant C1 is identified as a postsolution posing type. He arranges similar problems after solving the given problem. $\mathrm{C} 1 \mathrm{can}$ analyze the problems so that he can arrange relevant new problems. Then the $\mathrm{C} 1 \mathrm{can}$ choose the right concepts, procedures, and problem solving methods in solving the new problem, namely using a combination of substitution and elimination methods. After choosing the procedures to solving the problem, participant $\mathrm{C} 1$ can solve the problem that he made. Clearly, the results of data analysis of participants A1, B3 and C1 are presented in Table 3.

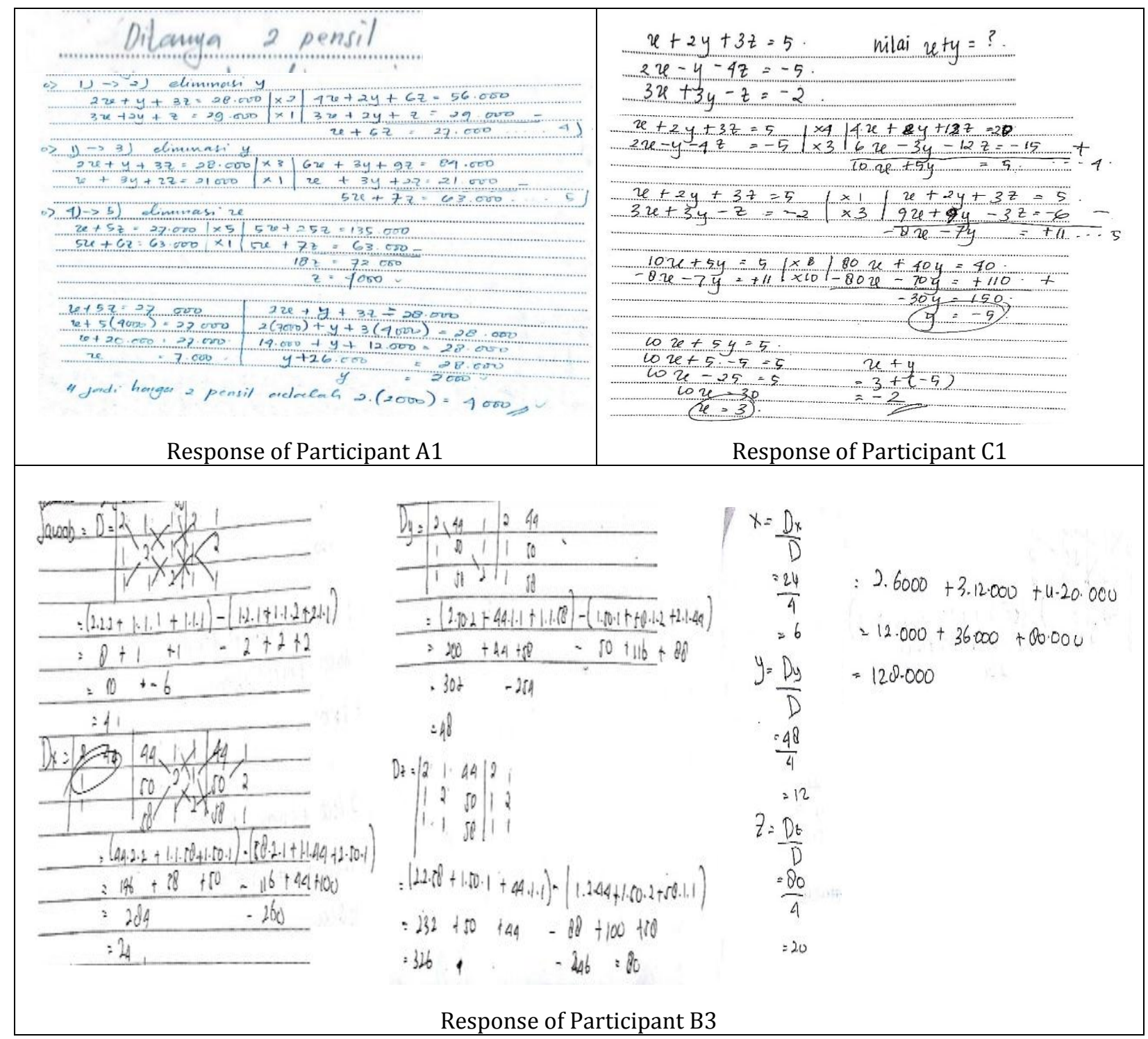

Figure 1. Response of participant A1, B3 and C1 
Table 3

Analysis results of participant A1, B3 and C1

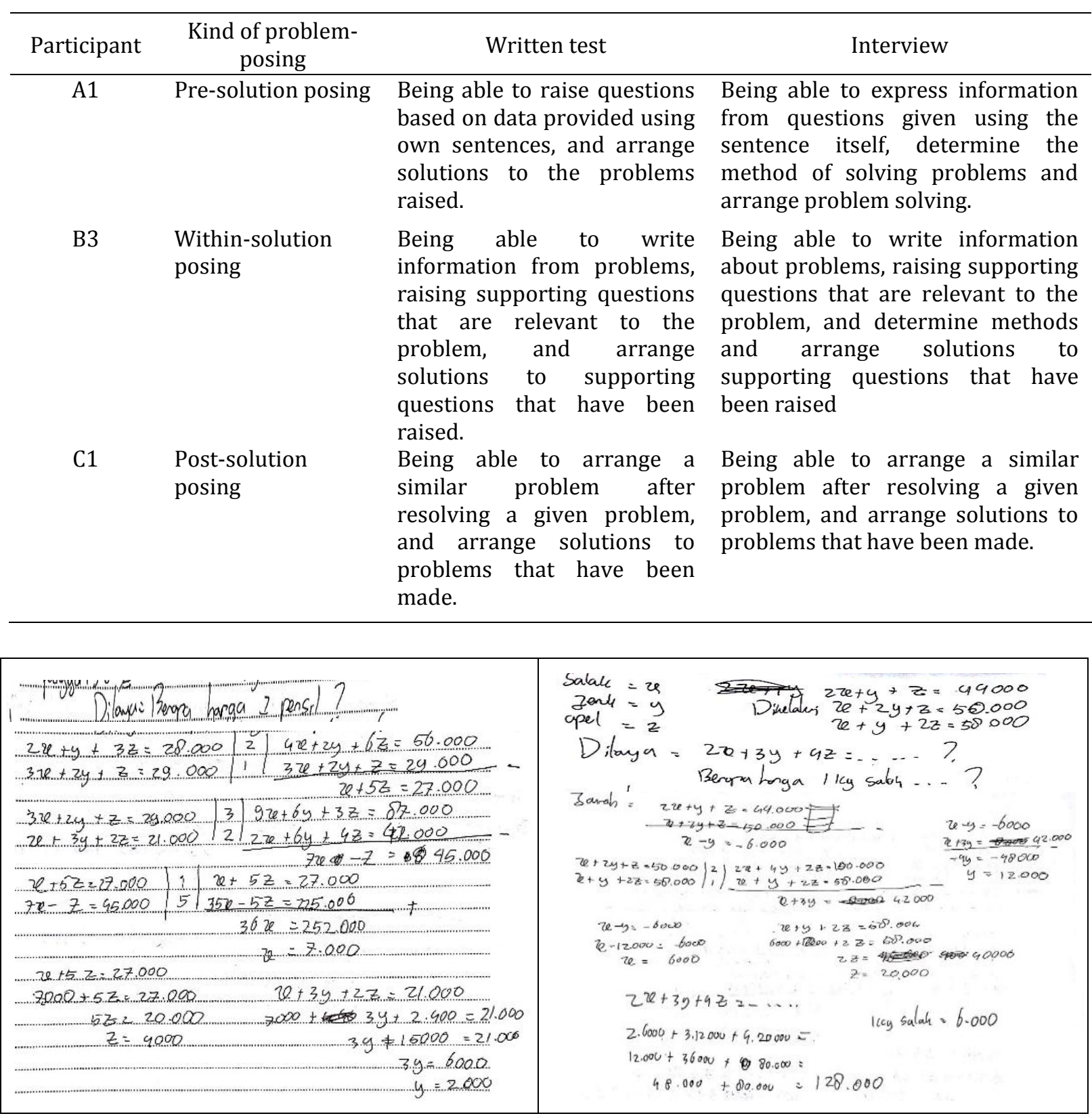

Figure 2. Response of participant D3

Figure 2 shows that D3 had the ability to pre-solution posing and within-solution posing. For the ability of pre-solution posing, it can be seen when the participant raises questions from the data provided, and arranges problem solving using mixed methods: elimination and substitution. The ability of within-solution posing can be seen from the participant can write what is given and asked of the problem, raise supporting questions relevant to the problem and arrange the resolution of the supporting questions and problems given correctly. Clearly, the results of data analysis of participant D3 are presented in Table 4. 
Table 4

Analysis results of participant D3

\begin{tabular}{lll}
\hline & \multicolumn{1}{c}{ Written test } & \multicolumn{1}{c}{ Interview } \\
\hline $\begin{array}{l}\text { Pre-solution } \\
\text { posing }\end{array}$ & $\begin{array}{l}\text { Being able to raise questions based on } \\
\text { data provided using own sentences, } \\
\text { and arrange solutions to the problems } \\
\text { raised. }\end{array}$ & $\begin{array}{l}\text { Being able to raise questions based on data } \\
\text { arrange solutions to the problems raised. }\end{array}$ \\
Within- & $\begin{array}{l}\text { Being able to write information from } \\
\text { problems, raising posing able to write information about } \\
\text { questions that are relevant to the } \\
\text { problem, and arrange solutions to } \\
\text { supporting questions that have been } \\
\text { raised. }\end{array}$
\end{tabular}

\begin{tabular}{|c|c|c|c|}
\hline $\begin{array}{l}\text { Pertanyaan. } \\
\Rightarrow \text { Berapakah harga sbukut } \\
10 \text { penhi' }+2 \text { Pengganis. }\end{array}$ & & $\begin{array}{l}3 u+y+4 z=8 \\
20+y+z=4 \\
2 u+y+z=10\end{array}$ & \\
\hline 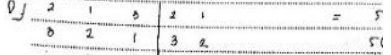 & \begin{tabular}{llll|l}
$D_{y}=2$ & 28 & 3 & 3 & 28 \\
& 39 & 1 & 3 & 29
\end{tabular} & $D=3 \quad 4 \quad 3 \quad$ & $D y=3 \quad 8 \quad 4 \quad \begin{array}{lll}3 & 8\end{array}$ \\
\hline $13=113=3$ & 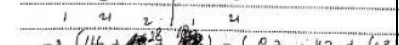 & \begin{tabular}{lll|ll}
2 & 1 & 1 & 2 & 1 \\
& 1 & 3 & 1
\end{tabular} & \begin{tabular}{lll|ll}
2 & 4 & 1 & 2 & 4 \\
& 10 & 7 &
\end{tabular} \\
\hline$\Rightarrow(8+1+24)-(6+6+6) \quad$ Jadi & $\Rightarrow(16+29)-(87+112+162$ & $=0(21+1+16)-(4+6+14)$ & $=0$ (x)ere $4(84+8+80)-(16+30+112)$ \\
\hline$\rightarrow 36-18=18 \quad$ lo $p$ & 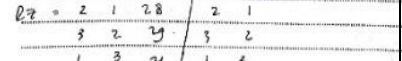 & $\Rightarrow 38-4=14$ & 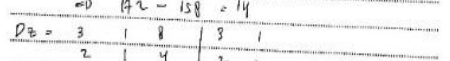 \\
\hline 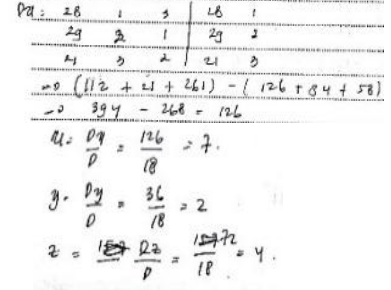 & 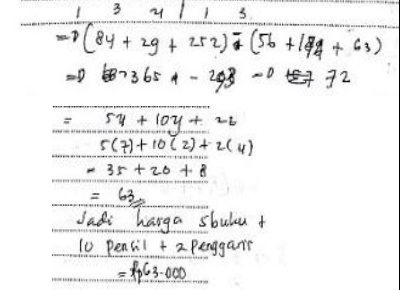 & 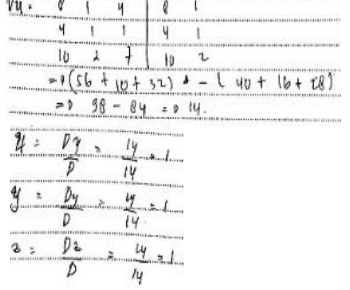 & 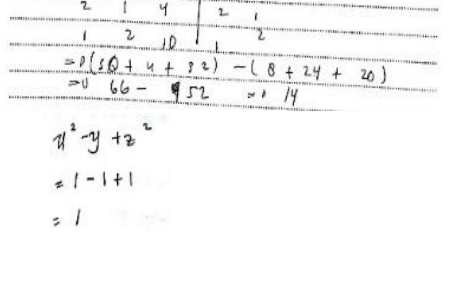 \\
\hline
\end{tabular}

Figure 3. Response of participant E2

Figure 3 clearly shows that E2 had the ability to pre-post solution posing and postsolution posing. For the ability of pre-solution posing, it can be seen when the participant raises questions from the data provided and can determine the problem solving method used and compile the problem solving that has been raised. The ability of post-solution posing can be seen from the participant can raise similar problems after solving the given problem, and can also arrange solutions to the problems that have been made. Clearly, the results of data analysis of participant E2 are presented in Table 5.

Table 5

Analysis results of participant E2

\begin{tabular}{lll}
\hline & \multicolumn{1}{c}{ Written test } & \multicolumn{1}{c}{ Interview } \\
\hline $\begin{array}{l}\text { Pre-solution } \\
\text { posing }\end{array}$ & $\begin{array}{l}\text { Being able to raise questions based } \\
\text { on data using own sentences, and } \\
\text { arrange solutions to problems that } \\
\text { have been raised. }\end{array}$ & $\begin{array}{l}\text { Being able to raise questions based on available } \\
\text { information, determine the solution to the } \\
\text { problem to be used, and can arrange solutions to } \\
\text { the problems that have been raised. }\end{array}$ \\
\hline
\end{tabular}




\begin{tabular}{|c|c|c|}
\hline $\begin{array}{l}\text { Post-solution } \\
\text { posing }\end{array}$ & $\begin{array}{l}\text { Being able to arrange the solution } \\
\text { to the problem given, put forward a } \\
\text { similar problem after solving the } \\
\text { problem given, and can arrange } \\
\text { solutions to the problems that have } \\
\text { been made. }\end{array}$ & $\begin{array}{l}\text { Being able to arrange the problem solving that is } \\
\text { given well, put forward similar problems, and can } \\
\text { determine the method of solving problems and } \\
\text { arrange solutions to the problems that have been } \\
\text { made. The subject explains the completion steps } \\
\text { using the understanding conveyed by the teacher. }\end{array}$ \\
\hline
\end{tabular}

Figure 4 shows that F3 had the ability to within-post solution posing and postsolution posing. For the ability within-solution posing, it can be seen when the participant can write what is given and what is asked, raise supporting questions that are relevant to the problem and arrange solutions to relevant supporting questions and use them to arrange the problem solving given. The ability of post-solution posing can be seen from the participant can raise similar problems after solving the given problem, and can also arrange solutions to the problems that have been made. Clearly, the results of data analysis of participant F3 are presented in Table 6.

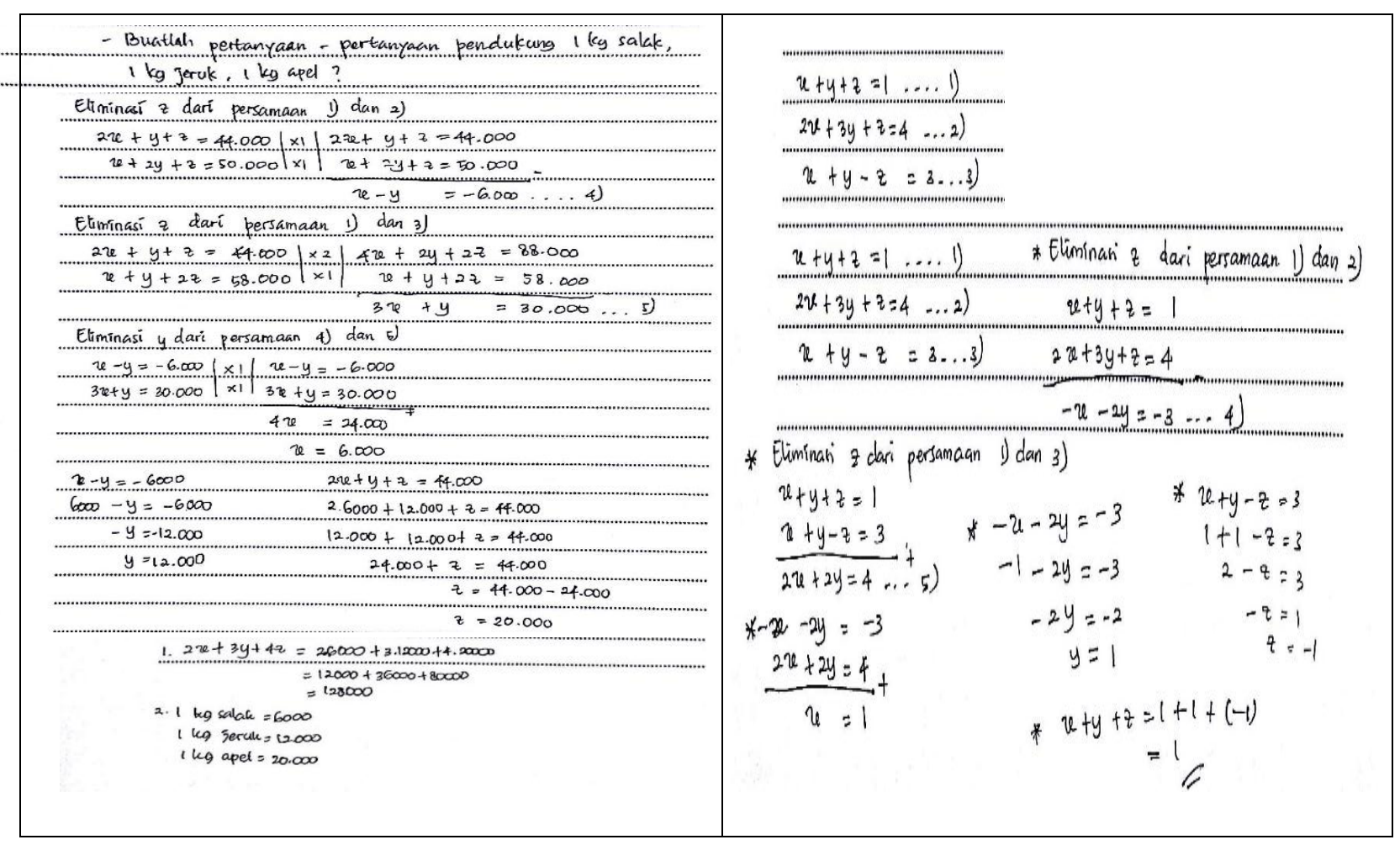

Figure 4.Response of participant F3

Table 6

Analysis results of participant F3

\begin{tabular}{lll}
\hline & \multicolumn{1}{c}{ Written test } & Interview \\
\hline Within- & Being able to write information from & Being able to write information about \\
solution & problems, raising supporting questions problems, raising supporting questions \\
posing & $\begin{array}{l}\text { that are relevant to the problem, and that are relevant to the problem, and } \\
\text { arrange solutions to supporting questions } \\
\text { that have been raised. }\end{array}$ & $\begin{array}{l}\text { determine methods and arrange solutions } \\
\text { to supporting questions that have been } \\
\text { raised }\end{array}$ \\
\hline
\end{tabular}




\begin{tabular}{|c|c|c|}
\hline & Written test & Interview \\
\hline $\begin{array}{l}\text { Post-solution } \\
\text { posing }\end{array}$ & $\begin{array}{l}\text { Being able to arrange the solution of the } \\
\text { problem given, can express similar } \\
\text { problems after solving the problem, and } \\
\text { can choose the concepts, procedures, } \\
\text { methods of solving problems that are } \\
\text { appropriate in solving the problems that } \\
\text { have been made. }\end{array}$ & $\begin{array}{l}\text { Being able to arrange the solution of the } \\
\text { problem given, can express similar } \\
\text { problems after solving the problem, and } \\
\text { can choose the concepts, procedures, } \\
\text { methods of solving problems that are } \\
\text { appropriate in solving the problems that } \\
\text { have been made. }\end{array}$ \\
\hline
\end{tabular}

Participant G5 had the ability to pre-within-post solution posing. For the ability of pre-solution posing, it can be seen when the participant can raise questions from the data provided, and arrange the problem solving that has been stated. The ability of withinsolution posing can be seen from the participant write what is given and what is asked of the problem given, raise supporting questions that are relevant to the given problem. The participant can determine the problem solving method used and arrange the resolution of supporting questions that are relevant to the given problem and use it to arrange the problem solving given. Meanwhile, the ability of post-solution posing can be seen from the participant to raise similar problems after solving the given problem and arrange the solution to the problem that has been made.

The results showed that only $20 \%$ of students had three classifications of problemposing abilities, namely pre-solution posing, within-solution posing, and post-solution posing. Students who have the ability to pre-solution posing can express problems from the data provided and arrange solutions to problems that have been raised. This is in line with Silver (1994) which explains pre-solution posing, in which a student makes a problem from a situation that is held/from a motivation factor. Arikan and Ünal (2015) states that presolution posing can train students to ask problems based on a story, diagram, picture, and representation. Students are trained to be able to relate the information they have to the material they have learned.

Students who have the ability within-solution posing can write information on a math problem, can express support questions relevant to the problem, and can arrange settlement of support questions relevant to a given problem. Problem solving when someone intentionally changes the purpose of a problem such as using a strategy that makes it simpler (Arofah \& Masriyah, 2019; Silver, 1994). This reinforces that withinsolution posing is related to the reformulation of the problem to be solved and considers the hypothesis and problem situation (Silver \& Cai, 1996). Furthermore, students who have the ability to post-solution posing can express similar problems after solving the given problem and can arrange solutions to the problems that have been made. Silver (1994) stated after solving a problem when experiences from the problem solving context are modified or applied to new situations. Post-solutions related to the change of information from a problem to a new problem to be solved (Rachmawati et al., $\underline{2019}$; Silver \& Cai, 1996).

Thus, the ability of problem posing really needs to be owned by students because it can make students actively learn mathematics (Barlow \& Cates, 2006), positively correlate with learning outcomes (Silver \& Cai, 1996), and can help students in developing ideas of problem solving (English, 1997; Xia, Lu \& Wang, 2008). Ayllón et al. (2016) and Xie and Masingila (2017) explain that there is a significant relationship between problem solving skills and problem posing. This is like a thought with Arofah and Masriyah (2019), English

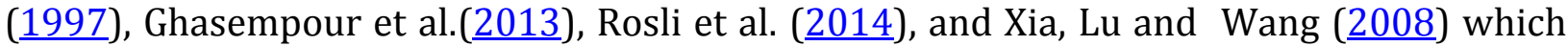
stated that the ability of problem posing can help students in developing ideas for problem solving. It is impossible to solve new problems without having relevant mathematical 
knowledge, developing new problems, and then solving them. Silver and Cai (1996) and Tuğrul ( $\underline{2010})$ show that students who have a good problem posing abilities also have good problem solving abilities.

\section{Conclusion}

Problem posing provides many benefits for students in learning mathematics, for example making students more active in learning and able to develop problem solving abilities. Students who have the ability to pre-solution posing can ask questions based on the data provided and can arrange problem solving. Students who have within-solution posing ability can write information from the problem and arrange the solution of the question correctly. Meanwhile, students who have the ability to post-solution posing can express similar problems and can arrange solutions to the problems that have been made. The fact that there are still many students who do not have problem posing skills needs to get the attention of mathematics teachers. Gradually the teacher needs to practice presolution posing, within-solution posing, and post-solution posing to the students. In subsequent research, it is necessary to explore the relationship between problem-posing and problem solving.

\section{Acknowledgment}

We would like to thank Mr. Ikham Ulil Albab who corrected this article.

\section{Bibliography}

Arikan, E. E., \& Ünal, H. (2015). Investigation of problem-solving and problem-posing abilities of seventh-grade students. Educational Sciences: Theory and Practice, 15(5), 1403-1416. Retrieved from https://files.eric.ed.gov/fulltext/EJ1101279.pdf

Arofah, D. N., \& Masriyah. (2019). Profil pengajuan masalah matematika siswa SMP ditinjau dari gaya kognitif reflektif dan impulsif. MATHEdunesa, 8(2), 209-215. Retrieved from https://jurnalmahasiswa.unesa.ac.id/index.php/mathedunesa/article/view/27975/ 25597

Ayllón, M. F., Gomez, I. A., \& Ballesta-Claver, J. (2016). Mathematical thinking and creativity through mathematical problem posing and solving. Journal of Educational PsychologyPropósitosy Representaciones, 4(1), 195-218. https://doi.org/10.20511/pyr2016.v4n1.89

Barlow, A. T., \& Cates, J. M. (2006). The impact of problem posing on elementary teachers' beliefs about mathematics and mathematics teaching. School Science and Mathematics, 106(2), 64-73. https://doi.org/10.1111/j.1949-8594.2006.tb18136.x

English, L. D. (1997). Promoting a problem-posing classroom. Teaching Children Mathematics, 4(3), 172-179. Retrieved From https://search.proquest.com/ openview/cdd66cae97b9482d93b4bb9e0cb35487/1?pq-origsite=gscholar\&cbl $=32876$

Ghasempour, Z., Bakar, N., \& Jahanshahloo, G. R. (2013). Innovation in teaching and learning through problem posing tasks and metacognitive strategies. International Journal of Pedagogical Innovations, 1(1), 53-62. Retrieved from https://platform.almanhal.com/Files/2/46793

Mahmudi, A. (2011). Problem posing untuk menilai hasil belajar matematika. Seminar Nasional Matematika Dan Pendidikan Matematika Matematika Dan Pendidikan Karakter Dalam Pembelajaran. Retrieved from http://eprints.uny.ac.id/7359/1/p3.pdf 
Miles, M. B., \& Huberman, A. M. (2002). The qualitative researcher's companion. California: Sage publications.

Moleong, J. L. (2008). Metodologi penulisan kualitatif, edisi revisi. Bandung: Remaja Rosdakarya.

Murtianto, Y. H., Muhtarom, M., Nizaruddin, N., \& Suryaningsih, S. (2019). Exploring student's productive thinking in solving algebra problem. TEM Journal - Technology, Education, Management, Informatics, 8(4), 1392-1397. https://doi.org/10.18421/TEM84-41

Rachmawati, Y. I., Sugandi, E., \& Prayitno, L. L. (2019). Senior high school students' ability in posing system of linear equations in two variables problems. JRAMathEdu (Journal of Research and Advances in Mathematics Education), 4(1), 57-65. https://doi.org/10.23917/jramathedu.v1i1.6954

Rosli, R., Capraro, M. M., \& Capraro, R. M. (2014). The Effects of problem posing on student mathematical learning: a meta-analysis. International Education Studies, 7(13), 227241. https://doi.org/10.5539/ies.v7n13p227

Rosli, R., Goldsby, D., \& Capraro, M. M. (2013). Assessing students' mathematical problemsolving and problem-posing skills. Asian Social Science, 9(16), 54-60. https://doi.org/10.5539/ass.v9n16p54

Silver, E. A. (1994). On mathematical problem posing. For the learning of mathematics. 14(1), 19-28. Retrieved from https://www.jstor.org/stable/40248099

Silver, E., \& Cai, J. (1996). An analysis of arithmetic problem posing by middle school students. Journal for Research in Mathematics Education, 27(5), 521-539. https://doi.org/10.2307/749846

Siswono, T. Y. E. (2011). Level of student's creative thinking in classroom mathematics. Educational Research and Reviews, 6(7), 548-553. Retrieved from http://www.academicjournals.org/ERR

Stoyanova, E. (2005). Problem-problem strategies used by years 8 and 9 students. AAMT Standards for Excellence in Teaching Mathematics in Australian Schools, 61(3), 6-11. Retrieved from https://files.eric.ed.gov/fulltext/E]743563.pdf

Tuğrul, K. (2010). The relation between problem posing and problem solving skills of prospective elementary mathematics teachers. Procedia Social and Behavioral Sciences, 27(5), 521-539. https://doi.org/10.1016/j.sbspro.2010.03.239

Xia, X., Lu, C., \& Wang, B. (2008). Research on mathematics instruction experiment based on problem posing. Journal of Mathematics Education, 1(1), 153-163. Retrieved from https://pdfs.semanticscholar.org/581a/4a00a72e81a5326fb58c72c681129050adf.p $\underline{\mathrm{df}}$

Xie, J., \& Masingila, J. O. (2017). Examining interactions between problem posing and problem solving with prospective primary teachers: A case of using fractions. Educational Studies in Mathematics, 96(1), 101-118. https://doi.org/10.1007/s10649-017-9760-9 


\section{APPENDIX}

1. Make a question from the following information, and find the solution!

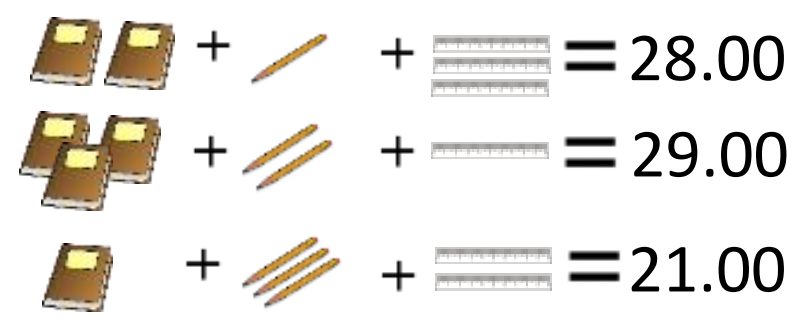

2. Dwi, Dita, and Fida buy fruits in the same shop. Dwi bought $2 \mathrm{~kg}$ thorny palm, $1 \mathrm{~kg}$ oranges, and $1 \mathrm{~kg}$ apples and had to pay Rp. 44,000.00. Dita bought $1 \mathrm{~kg}$ thorny palm, $2 \mathrm{~kg}$ oranges, and $1 \mathrm{~kg}$ apples and had to pay Rp. 50,000.00. Fida pays Rp. 58,000.00 to buy $1 \mathrm{~kg}$ thorny palm, $1 \mathrm{~kg}$ oranges, and $2 \mathrm{~kg}$ apples. If Nia wants to buy $2 \mathrm{~kg}$ thorny palm, $3 \mathrm{~kg}$ oranges, and $4 \mathrm{~kg}$ apples, how much money does Nia have to pay? Based on the information above, create supporting questions to help resolve the problem above and solve it!

3. $x, y$, and $z$ are the solutions of the following system of linear equations:

$$
\begin{aligned}
& 3 x+4 y-5 z=12 \\
& 2 x+5 y-z=17 \\
& 6 x-2 y+3 z=17
\end{aligned}
$$

Create a new problem and find the solution! 